\begin{abstract}
Toin APSA in Boston for the 114th Annual Meeting to address the latest scholarship in political science while exploring the theme, "Democracy and Its Discontents." APSA and the 2018 program chairs Henry Farrell, The George Washington University, and Anna Grzymala-Busse, Stanford University, look forward to your participation in panels and sessions prepared by APSA's numerous divisions and related groups at the 2018 meeting.
\end{abstract}

\section{PROGRAM SCHEDULE}

The annual meeting program is available at: https://connect.apsanet.org/apsa2018/. Times are subject to change. Registration is still available through August 24!

\section{THEME PANELS}

The official theme panels for the 2018 Annual Meeting are listed to the right. Review the participants on each panel and find detailed descriptions of each at: https://connect. apsanet.org/apsa2018/theme-panels/. If you're a panel participant, be sure to submit your paper to chairs and discussants by August 13.

\section{PRECONFERENCE SHORT COURSES}

Consider taking a short course! Short courses will take place prior to the annual meeting on Wednesday, August 29. They provide diverse opportunities, either half day or full day, for professional development and offer attendees the chance to connect with scholars from a range of backgrounds. Preregistration for short courses is required and is $\$ 25$ per short course. Registration for short courses is available on the Annual Meeting registration page, as part of the registration process. See a full list of short courses available at: https://connect.apsanet.org/apsa2018/preconference-short-courses/. .

\title{
List of Theme Panels
}

- Changing Face of Democracy and the Rising Discontent of the Citizens

- Comparative Perspectives on US Populism and Potential for Democratic Erosion

- Congress and President Trump in an Age of Discontent

- Culture and Discontents: New Approaches

- Democracy and its Discontents in Africa

- Democracy and its Discontents in the Middle East

- Democracy and its Discontents: The Failing Politics of Climate Adaptation

- Democracy in America?

- Democratic Backsliding in SE Asia

- Democratic Backsliding in Advanced Democracies

- Democratic Discontent, Administrative Instability, and the Capacity to Govern

- Discontent with Gender Justice: Backlash, Resistance, and Opposition Worldwide

- Dynastic Politics and Democratic Discontent

- Economic Discontent and Political Backlash

- Electoral Shocks: Understanding the Volatile Voter in a Turbulent World

- Elites, Political Parties, and Democracy's Discontents

- Erosion of Democracy: Populism and its Causes

- Explicit Appeals to Prejudice in the Trump Era

- Health Policy and Democratic Discontent: The ACA in Comparative Perspective
- How Democratic is American Foreign Policy? How Democratic Should It Be?

- How to Write about Your Research for the Monkey Cage

- Inequality, Redistribution, and Democracy

- Information Warfare, Past and Present

- Intersectionality and Political Mobilization

- Is it Regime Change? Comparative and Historical Reflections on the US

- Measuring Democratic Erosion

- Mini Conference on Populism in Europe

- New Approaches to Corruption: Theory, Method, and Measurement

- Oligarchic Tendencies in US Politics

- Political Communication in an Era of Polarization and Social Media

- Power, Persuasion, and Disruption in Activist Politics

- Race, Class, and the Space for Local Democracy: New Views, New Voices

- State of the Discipline in the Era of Democratic Discontent

- Teaching Erosion of Democracy

- The Crisis of Democracy: A Roundtable of Political Science Thought

- The Effects of Protests in the US

- The Erosion of Democracy and its Consequences

- The Liberal Order Under Stress

- The Resilience and Erosion of Democracy

- Theorizing Democratic Participation: Populist Perils and Deliberative Promises

- Voters or the Market? The Politics of Credibility Since the Great Recession 